\title{
THE INFLUENCE OF MATERNAL AND CHILD HEALTH SERVICES ON NEONATAL DEATH OF LOW BIRTH WEIGHT NEONATES IN ACEH PROVINCE
}

\author{
Satrinawati Berkat \\ Department of Midwifery, Health Polytechnic of Aceh (Poltekkes Kemenkes Aceh), Aceh Province, Indonesia \\ Corresponding Author: Satrinawati Berkat \\ Email: Satrin_aceh@yahoo.com
}

\begin{abstract}
Low birth weight (LBW) is one of the most crucial problem related to neonatal mortality and infant mortality. The LBW is defined as babies born with a birth weight less than 2500 grams. LBW does not only contribute to neonatal morbidity, but may lead to neonatal mortality. This study aim to determine the influence of maternal and child health services $(\mathrm{MCH})$ services to neonatal death among LBW babies in Aceh province, Indonesia. This study is observational study with mix method, using quantitative (Unmatched case control study) and qualitative (case study). The study was conducted between 2011-2015 in 8 district/municipality in Aceh Province, Indonesia. Total sample for quantitative study was 500 neonates (1:1), 250 neonates who died in neonatal period (case) and 250 LBW neonates who survived in the neonatal period (control group). Meanwhile, the total sample for qualitative study was 22, there were 12 (mother) and 10 (midwife). The result of A simple logistic regression analysis for MCH factors found that 4 of 7 variable were significant association with neonatal death among $L B W(P$ value $<0.05)$, these variables include: Antenatal care (ANC), place of delivery, level of health facilities and neonatal visit. Multiple logistic regression found the ANC has a strongest influence on neonatal death among LBW babies in Aceh Province (OR=3.6; 95\% CI: 2.3-5.7). The LBW neonates who were born to mothers who received number of ANC equal to or less than 3 times had a 3.6 times higher risk of death, than neonates who were born to mothers who received ANC $\geq 4$ times. The appropriate of health services in health facilities are needed to reduce the NMR and improve the health of neonate.
\end{abstract}

Keywords: MCH, low birth weight, neonatal death

\section{INTRODUCTION}

According to the Millennium Development Goals (MDGs) report, in 2015 maternal mortality ratio (MMR) and neonatal mortality rate (NMR) still high in the world. Despite a significant reduction the MMR from an estimated $523 / 100,000$ live births in 1990 to $216 / 100,000$ live births in 2015 , but the rate of decline is less than half of what is needed to achieve the MDG target of a threequarters reduction in the mortality ratio between 1990 and $2015^{(1)}$. Global NMR has declined by 3.1 per cent annually since 2000. In 2015, NMR in the world was $19 / 1000$ livebirth. Likewise, the decline of neonatal mortality was slower than the decline in post-neonatal mortality (age 1-11 months) and among children aged 1-4 years for both the $1990-2000$ and $2000-2017$ periods. ${ }^{(2)}$. At the same time MMR in Indonesia was 126/100,000 live births and NMR was 14/1000 live births ${ }^{(3)}$. Even though this number was lower than the average mortality rate in the world, but the number was still high for the Southeast Asia region ${ }^{(4)}$.

Women die as a result of complications during and following pregnancy and childbirth. Most of these complications develop during pregnancy and most are preventable or treatable. Other complications may exist before pregnancy but are worsened during pregnancy, especially if not managed as part of the woman's care. ${ }^{(5)}$. The major complications that account for nearly $75 \%$ of all maternal deaths are: severe bleeding (mostly bleeding after childbirth), infections (usually after childbirth), high blood pressure during pregnancy (pre-eclampsia and eclampsia), complications from delivery and unsafe abortion (6) and the remainder are caused by or associated with diseases such as malaria, and AIDS during pregnancy ${ }^{(5)}$.

Meanwhile, the cause of specific neonatal mortality in few country in South Asia include: Infection, preterm, asphyxia, other causes and congenital(7). Meanwhile, in Indonesia the main causes of neonatal mortality in 2015 were prematurity (35.5\%), birth asphyxia and birth trauma $(21.6 \%)$ congenital anomalies $(17.1 \%)$, sepsis (13\%) and other $5.4 \%{ }^{(3)}$. Prematurity will cause the babies to born with low birth weight (LBW).

Low birth weight is defined as babies born with a birth weight less than 2500 grams ${ }^{(8)}$. The LBW categorized into three type, these are: Pre term birth (births before 37 completed weeks of gestation), Intra uterine growth restriction/ IUGR (the new-borns are significantly smaller than average for the length of time the foetus (baby) is in the mother's uterus) and a both ${ }^{(9)}$. Many factor related to low LBW, these include: inappropriate antenatal care (ANC), maternal high, lack of iron and calcium supplement (10), 
chronic hypertension, history previous of LBW, anaemia ${ }^{(11)}$, maternal age, income, education, and resident area ${ }^{(12)}$.

The LBW does not only contribute to neonatal morbidity, but may lead to neonatal mortality. Even though LBW is not the immediate cause of mortality, it is a major contributor and may jeopardize a new-borns chances of survival. Risk factors of LBW death in a neonatal period are: maternal factors $\left.{ }^{(13}\right)$, exclusive of breastfeeding $\left.{ }^{(14}\right)$, Smoking of father ${ }^{(15)}$, weight of neonate $\left.{ }^{(16}\right)$, multiple gestation, small gestation age, and sex (17), etc.

In addition, LBW does not only affect new-borns growth but also may affect their entire life. It is the main cause of poor childhood growth and highrisk diseases in the adult, such as diabetes, hypertension and cardiovascular. For baby girls, they are more likely to have LBW babies when they become a mothers ${ }^{(8)}$.

In 2013, nearly 22 million new-born-an estimated 16 per cent of all babies born globally that year were LBW. Among regions, South Asia has the highest incidence of LBW, there was $66 \%$ of all birth (18). In Indonesia, between 2013-2017, prevalence rate of LWB was $7 \%$ of live births $\left.{ }^{(19}\right)$. The reduction of LBW rates will have implications for the reduction of neonatal mortality.

Integrated and comprehensive health services are needed to reduce MMR and NMR, and in Indonesia this is called Maternal and Child Health $(\mathrm{MCH})$ services. Many efforts have been made in Indonesia to improve the MMR and NMR, which aims to improve maternal and child health and reduce morbidity and mortality. These programs include ANC at least 4 times during pregnancy, delivery assisted by the qualified health care worker and in the health facilities, postpartum services, neonatal visits, contraceptive services, etc. ${ }^{(20)(21)}$. The result of these programmes has significantly reduced the NMR, IMR and U5MR in Indonesia during the last two decades.

Aceh Province is one of 34 provinces in Indonesia. Aceh province is located at the western tip of Indonesia. Between 2013-2017, neonatal mortality in Aceh province was $11 / 1000$ live birth (22). At the same time, prevalence rate of LBW babies in Aceh province was $6.5 \%$, the number was higher than prevalence rate in Indonesia (6.2\%) (23). The high number of LBW babies are expected to increase the neonatal mortality.

Many health programmes have been implemented in Indonesia and Aceh province to reduce NMR. Generally, these programmes have been effective and have gone well in achieving national targets and in some other province in Indonesia, but the results were not well in Aceh Province. Based on these conditions, this study aims to determine the influence of $\mathrm{MCH}$ services to neonatal death among LBW in Aceh province, Indonesia.

\section{METHODOLOGY}

\section{Study design and population}

An observational study with mix method, quantitative (Unmatched case control study) and qualitative (case study).

\section{Quantitative Method}

Population and sample

Population for this study was LBW neonates in the Aceh Province (Indonesia) delivered between 2011 to 2015, include all those who survived or died during the neonatal period. Sample were divided into two groups: LBW neonates who died in the neonatal period (case group) and LBW neonates who survived in the neonatal period (control group). Inclusion and exclusion criteria shown in table 1.

Nonprobability sampling used for determining the sample, there were; purposive sampling was used to select the district that were study sites and consecutive sampling was used to select cases and controls in the district and sub district. Formula of Fless was used for calculating the sample size. The total sample was 500 neonates (1:1), 250 case and 250 control.

\section{Data Collection}

Data collection started in early February 2012 and completed in August 2015, in 8 districts/ municipalities in Aceh province. Data collected base on a questionnaire that filled by parent and assisted by the enumerator when the study conducted. The questionnaire developed by the researcher has 2 sections, the include: a). characteristic of the neonate, mother, and father, b). Maternal and child health services since pregnancy to neonatal period.

\section{Variables:}

The dependent variable this study was neonatal mortality that divided into two factors; neonate who died during neonatal period (case group) and neonate who remain alive during neonatal period (control group). Independent variables were: ANC, place of delivery, birth attendant, mode of delivery, referral and neonatal visit.

Data analysis

Descriptive statistic was used for univariate analysis, simple logistic regression was used for bivariate analysis and multiple logistic regression was used for analyse of determinant factors.

\section{B. Qualitative Method \\ Population and sample}

Population of qualitative study were: mother who delivered LBW neonate between 2011 to 2015 in Aceh Province and health care worker (midwife) who were the birth attendant of LBW babies between 2011-2015 in Aceh Province. 
Inclusion and exclusion criteria shown in table 2. Nonprobability sampling used for determining the sample, there was quota sampling for selecting the mother as sample and purposive sampling for selecting the midwife (health care worker) as sample. Total number of mothers as sample was 12 and midwife was 10 .

\section{Data Collection}

The qualitative data were obtained through an indepth interview with mother/family and midwife and the guideline was the semi-structured interview

Data analysis

Analysis of data performed manually

Table 1: Inclusion and Exclusion Criteria

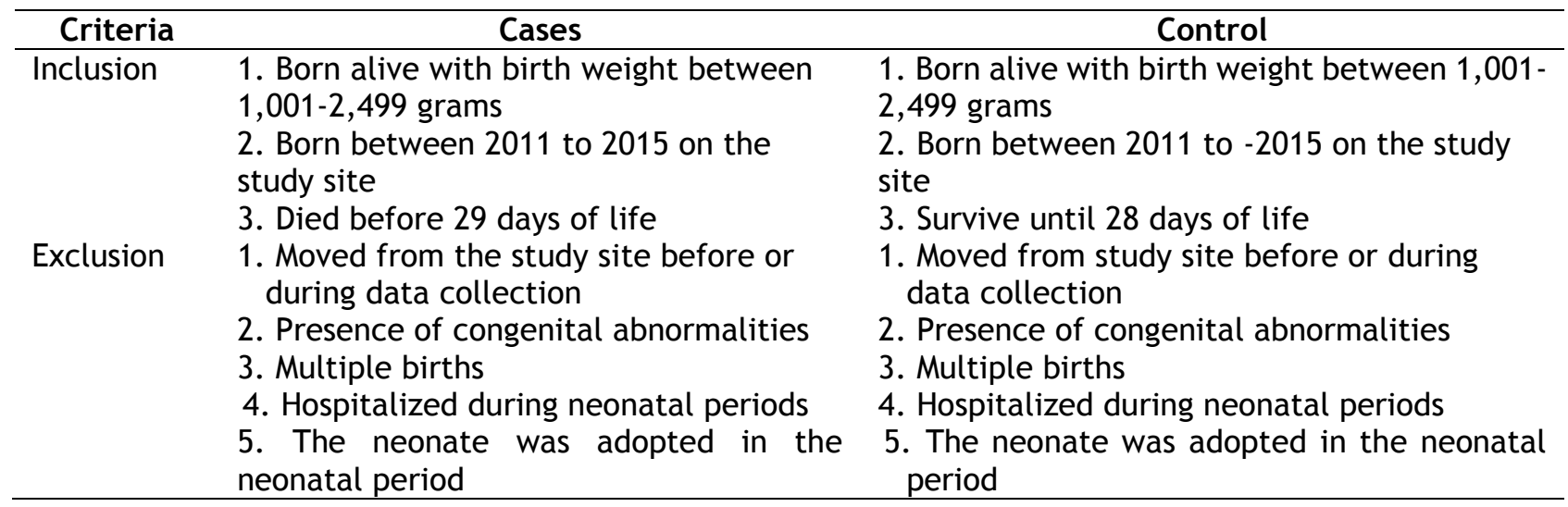

Table 2: Inclusion and exclusion criteria for qualitative study

\begin{tabular}{|c|c|c|}
\hline CRITERIA & Mother & Midwife \\
\hline Inclusion & $\begin{array}{l}\text { 1. Respondent of the } \\
\text { quantitative study. } \\
\text { 2. Educational level: Minimum, } \\
\text { Senior high School. } \\
\text { 3. The biological mother of the } \\
\text { neonate. }\end{array}$ & $\begin{array}{l}\text { 1. Minimum level of education: } \\
\text { Diploma III of midwifery. } \\
\text { 2. Has been working as a midwife for } \\
\text { a minimum of } 10 \text { years. }\end{array}$ \\
\hline Exclusion & $\begin{array}{l}\text { 1. Not fluent of Indonesia } \\
\text { language. } \\
\text { 2. Cannot communicate well. }\end{array}$ & $\begin{array}{l}\text { Has not practice as a midwife in a } \\
\text { health facility for at least a year (only } \\
\text { working as administrator at office). }\end{array}$ \\
\hline
\end{tabular}

\section{RESULT}

\section{Descriptive analysis}

Table 3 shows the description of the characteristic of neonate, mother and father. The characteristic of neonate is divide into sex, birth weight and gestational age. Characteristic of sex show that among those in the case group, 101 (40.4\%) neonates were girls, and 149 (59.6\%) neonates were boys. In the control group, 140 neonates $(56 \%)$ were girls and 110 neonates were boys $(44 \%)$. The birth weight showed that 171 $(68.4 \%)$ neonates in the case group were born with weight $\geq 1500$ grams and 79 (31.6\%) neonates were born with weight $<1500$ grams. In the other group, 243 neonates $(97.2 \%)$ were born with weight between 1500- 2499 grams and 7 (2.8\%) for weight $<1500 \mathrm{~g}$. The mean birth weight in the case group was 1728 grams and the standard deviation (SD) was 416.8. Meanwhile, the mean birth weight in control group was 2063 grams with SD of 283.5. The gestational age variable show that 44 neonates $(17.6 \%)$ in the case group were born full term and 206 neonates $(82.4 \%)$ were born preterm. Furthermore, $103 \quad(41.2 \%)$ neonates in the control group were born full term and 147 neonates $(58.8 \%)$ were born preterm. The mean gestational age in the case group was 32 weeks with SD of 4 , and the mean in the control group was 35.1 weeks with SD of 3.3.

Characteristics of mothers consist of age, birth interval, parity and education level. The characteristic of mother age show that most of the mothers recruited were aged between 20-35 years old (low risk). In the case group, 182 (72.8 $\%$ ) of mothers were in 20-35 years old age group and $211(84.4 \%)$ were in the control group. The number of mothers who delivered at the age of < 20 and $>35$ years old were $68(27.2 \%)$ in the case group and $39(15.6 \%)$ in the control group. The mean age of mothers in the case group was 28.7 years with SD of 6.6. Meanwhile, the age of mothers in the control group was 27.6 years with SD of 5.7 years. The birth interval was described as low risk (2-5 years from previous pregnancy) 
and high risk $(<2$ and $>5$ years from previous delivery) categories. There were165 (66\%) mothers delivered in the low risk category from case group and $201(80.4 \%)$ mothers from the control group. There were 85 (34 \%) mothers in the case group and $49(19.6 \%)$ in the control group from high risk category of birth interval. The mean birth interval in the case group was $2.1 \pm$ 2.3 , and in the control group was $2.3 \pm 2.3$.

The parity shows that $134(53.6 \%)$ mothers in the case group and 147 (58.8\%) mothers in the control group delivered in the low risk category (the 2nd to 4th pregnancy). Mothers who delivered in the high-risk category (1st or $\geq 5$ th pregnancy) were $116(46.4 \%)$ in the case group and 103 (41.2\%) mothers in the control group. The mean value of parity in case group was 2.9 times with SD of 1.7, while in the control group was $2.4 \pm 1.4$. The maternal education level, $86(34.4 \%)$ mothers in case group graduated from senior high school, 80 (32\%) mothers graduated from junior high school, $55(22 \%)$ mothers graduated from elementary school, and $7(2.8 \%)$ mothers graduated with a degree. In the control group, 99 (39.6\%) mothers graduated from senior high school, 68 (27.2\%) mothers graduated from junior high school, 47 $(18.8 \%)$ mothers graduated from elementary school and 26 (10.4\%) mothers obtained a diploma and 10 mothers had a bachelor degree.

Characteristic of father show that 103 (41.2\%) fathers in the case group graduated from senior high school and $4(1.6 \%)$ graduated with a college diploma. In the control group, 95 (38\%) fathers graduated from senior high school and 2 (0.8\%) graduated with a master's degree. Meanwhile, the family income as stated with median income was (IDR 1,500,000). The sample was divided into two groups; high income (family income > IDR $1,500,000$ per month) and low income (family income $\leq$ IDR 1,500,000 per month). In the case group, $143 \quad(57.2 \%)$ families were high income and107 $(42.8 \%)$ families were low income. In the control group, $175(70.0 \%)$ families had high income and 75 (30.0\%) families had low income.

Table 4 describes the characteristics of $\mathrm{MCH}$ services received by mothers from pregnancy to delivery and the services provided to neonates from birth until the neonatal period. The $\mathrm{MCH}$ services consisted of six variables: ANC, place of delivery, birth attendant, mode of delivery, referral, and neonatal visit. The ANC variable show that $140(56 \%)$ mothers in the case group received appropriate care (pregnancy examination $\geq 4$ times) as well as 205 (82\%) mothers in the control group. Mothers who did not receive appropriate care (pregnancy examination $<4$ times) in the case group was $110(44 \%)$ and in the control group was $45(18 \%)$ mothers. The mean ANC in the case group was 3.7 times with SD of 2.0, and the mean ANC in the control group was $5.0 \pm 2.8$.

The place of delivery variable showed that 104 $(41.6 \%)$ of mothers in the case group delivered their neonates at home and $3(1.2 \%)$ of the mothers delivered at the private clinic. In the control group, 79 (31.6\%) of the mothers delivered at home and only $1(0.4 \%)$ mother delivered at Posyandu. The level of health facilities variable showed that $63(43.4 \%)$ of 145 $\mathrm{n}$ LBW neonates whose birth was in the level 1 health facilities while those whose birth were in level 2 health facility was $82(56.6 \%)$ in the case group. In the control group, $103(60.6 \%)$ of 170 neonates were born in level 1 health facilities, and $67(39.4 \%)$ were born in the level 2 health facilities.

For the birth attendant variable, it indicates that those $175(70 \%)$ deliveries were in the case group assisted by a midwife and $22(8.8 \%)$ deliveries were assisted by TBA. In the control group, 194 $(77.6 \%)$ deliveries were assisted by a midwife and 8 (3.2\%) deliveries were assisted by TBA. The mode of delivery variable showed that $213(85.2 \%)$ deliveries were normal in case group and $1(0.4 \%)$ delivery used vacuum extraction. In the control group, $209(83.6 \%)$ deliveries were normal and none used vacuum extraction.

Referral variable indicates that $94(56.0 \%)$ of neonates with LBW in case group did not refer to community health care in sub- district (Puskesmas) or hospital after birth and 74 (44.0\%) of LBW did refer. In the control group, 147 (86.4 $\%)$ of neonates with LBW did not refer and 23 (13.6 $\%)$ of LBW did refer. The total sample analysed in this variable was 338 , and the neonates who were born in Puskesmas or hospital were excluded. The neonatal visit variable showed that $239(95.6 \%)$ of neonates in the case group received appropriate care. In the control group, 198 (79.2 $\%)$ neonates received appropriate.

\section{Bivariate Analysis:}

There were 7 variables in $\mathrm{MCH}$ services analysed with simple logistic regression. The 7 variables included ANC, place of delivery, level of health facility, birth attendant, mode of delivery, referral and neonatal visit. The study found a significant association between ANC and neonatal mortality $(\mathrm{p}<0.001)$ with OR of $3.57(95 \% \mathrm{Cl}$ : 2.38- 5.38). Neonates who were born to mothers who did not have ANC or had $<4$ examinations during their pregnancy times had a more than 3 times greater risk of death than neonates who were born to mothers who had $\geq 4$ times examinations or ANC during their pregnancy. 
Table 3: Characteristic of neonates, mother and father

\begin{tabular}{|c|c|c|c|c|c|}
\hline \multirow[t]{2}{*}{ Characteristics } & \multicolumn{2}{|c|}{ Case (250) } & \multicolumn{3}{|c|}{ Control (250) } \\
\hline & $\mathbf{n}$ & $\%$ & $\mathrm{n}$ & & $\%$ \\
\hline \multicolumn{6}{|l|}{ a. Neonate } \\
\hline - Girl & 101 & 40.4 & 140 & & 56.0 \\
\hline - Boy & 149 & 59.6 & 110 & & 44.0 \\
\hline \multicolumn{6}{|l|}{ Birth weight } \\
\hline - MLBW (1500-2499 grams) & 171 & 68.4 & 243 & & 97.2 \\
\hline - VLBW (1001- 1499 grams) & 79 & 31.6 & 7 & & 2.8 \\
\hline Mean \pm sd & $1728 \pm$ & 416.8 & $2,063 \pm$ & 283.5 & \\
\hline \multicolumn{6}{|l|}{ Gestational Age } \\
\hline - Full term ( $\geq 37$ weeks) & 44 & 17.6 & 103 & & 41.2 \\
\hline - Pre term (<37 weeks) & 206 & 82.4 & 147 & & 58.8 \\
\hline Mean $\pm \mathrm{sd}$ & $32 \pm 4.0$ & & $35.1 \pm 3.3$ & & \\
\hline \multicolumn{6}{|l|}{ b.Mother } \\
\hline \multicolumn{6}{|l|}{ Age } \\
\hline - Low risk (20-35 years old) & 182 & 72.8 & 211 & & 84.4 \\
\hline - High risk $(<20$ or $>35$ years old & 68 & 27.2 & 39 & & 15.6 \\
\hline Mean \pm sd & $28.7 \pm 6.6$ & & $28.7 \pm 6.6$ & & \\
\hline \multicolumn{6}{|l|}{ Birth interval } \\
\hline - Low risk (between 2-5 years) & 165 & 66.0 & 201 & & 80.4 \\
\hline - High risk (<2years or $>5$ years) & 85 & 34.0 & 49 & & 19.6 \\
\hline Mean \pm sd & $2.1 \pm 2.3$ & & $2.3 \pm 2.4$ & & \\
\hline \multicolumn{6}{|l|}{ Parity } \\
\hline - Low risk (2-4 times) & 134 & 53.6 & 147 & & 58.8 \\
\hline - High risk ( 1 or $\geq 5$ times) & 116 & 46.4 & 103 & & 41.2 \\
\hline Mean \pm sd & $2.9 \pm 1.7$ & & $2.4 \pm 1.4$ & & \\
\hline \multicolumn{6}{|l|}{ Education level } \\
\hline - Elementary school & 55 & 22.0 & 47 & & 18.8 \\
\hline - Junior high school & 80 & 32.0 & 68 & & 27.2 \\
\hline - Senior high school & 86 & 34.0 & 99 & & 39.6 \\
\hline - Diploma & 22 & 8.8 & 26 & & 10.4 \\
\hline - Degree & 7 & 2.8 & 10 & & 4.0 \\
\hline \multicolumn{6}{|l|}{ b. Father } \\
\hline \multicolumn{6}{|l|}{ Education level } \\
\hline - Elementary school & 39 & 15.6 & 42 & & 16.8 \\
\hline - Junior high school & 86 & 34.4 & 79 & & 31.6 \\
\hline - Senior high school & 103 & 41.2 & 95 & & 38.0 \\
\hline - Diploma & 4 & 1,6 & 14 & & 5.6 \\
\hline - Degree & 18 & 7.2 & 18 & & 7.2 \\
\hline - Master & 0 & 0.0 & 2 & & 0,8 \\
\hline \multicolumn{6}{|l|}{ Family income } \\
\hline - High income & 143 & 57.2 & 175 & & 70.0 \\
\hline - Low income & 107 & 42.8 & 75 & & 30.0 \\
\hline Median IDR: $1.500,000,-$ & & & & & \\
\hline
\end{tabular}

Place of delivery was significantly associated with neonatal mortality among LBW neonates $(\mathrm{p}<$ 0.05 ) with $\mathrm{OR} 1.53$ (95\% Cl: 1.0-2.21). Neonates born at home had 1.5 times greater risk of death than neonates born at health facilities. The study also found that the level of the health facilities was not significantly associated with neonatal mortality among LBW neonates $(p<0.05)$ with OR1.00 (95\% Cl: 1.00- 1.01). The result of a simple logistic regression for the birth attendants variable found that there was an association between birth attendants and neonatal mortality 
among LBW neonates $(\mathrm{P}<0.05)$ with $\mathrm{OR}$ of 2.91 $(95 \% \mathrm{Cl}: 1.27-26.68)$. Neonates whose birth assisted by TBA had 2.9 times greater risk of death than neonates whose births were assisted by health workers.

A simple logistic regression analysis for maternal factors found that there was no association between mode of delivery and referral with neonatal mortality among LBW neonates ( $p$ value $>0.05$ ). The data analysis found that there was a significant association between neonatal visits and neonatal mortality among LBW neonates ( $\mathrm{p}<$ 0.01 ) with OR 0.17 (95\% Cl: 0.8- 0.34).

\section{Multivariate Analysis}

For determining factors that influence neonatal death among low birth weight neonates, multiple logistic regressions were used. A likelihood ratio test was used for analysis because this study involved unmatched case control. With the simple logistic regression, results show that 5 out of the 7 variables had a $p$ value $<0.25$. All variables were entered for analyses, and these variables include, number of pregnancy examinations or antenatal care (ANC), place of delivery, level of health facility, birth attendants and neonatal visit.

Table 6 describes the results of multiple logistic regression. The strongest influence of neonatal death in this study was ANC. Neonates who were born to mothers who did not have ANC or had ANC $<4$ times had 3.6 times greater risk of death than neonates who were born to mothers who had $\geq 4$ examinations during their pregnancy $(\mathrm{OR} 3.5 ; \mathrm{Cl}$ $95 \%: 2.36-5.76)$. The second strongest influence of neonatal death was place of delivery. Neonates who were born at home had 1.2 times greater risk of death than neonates who were born in health facilities (OR 1.2; CI $95 \%: 1.1$ - 1.4). The third strongest influence was level of health facility. Neonates who were born in health facility level 1 (community health centre and private midwifery practice) had 1 times greater risk of death than neonates who were born in health facility level 2 , such hospital type A-D (OR 1.0 ; Cl $95 \%: 1.00$ 1.23). The weakest influence of neonatal mortality among LBW neonates was neonatal visits. Neonates who were provided with services such as home visits according to the standard by health workers were protected from death than neonates who received inappropriate care (OR 0.13; Cl $95 \%$ : 0.68 - 0.28).

\section{DISCUSSION}

Maternal and child health services has a great effect on infant survival, especially in the neonatal period. There were 4 factors that affected the neonatal mortality of the LBW neonates, these are: ANC, place of delivery, level of health facility and neonatal visit. This study concluded that ANC was a stronger predictor or determinant factors in neonatal mortality among the LBW neonates. The LBW neonates who were born to mothers who received number ANC visit equal to 3 times had a 3.6 times higher risk of death, than neonates who were born to mothers who received ANC $\geq 4$ times. Several previous studies indicated the same result with the present study(24),(25), (26), (27). In 2015, coverage of the 4th ANC in Indonesia was $87.5 \%$, and in Aceh province $75.6 \%{ }^{(28)}$.

The primary objective of antenatal care is to establish contact with the women, identify and manage current and potential risks and problems. This creates the opportunity for the woman and her health care provider to establish a delivery plan based on her unique needs, resources and circumstances. The delivery plan identifies her intentions about where and with whom she intends to give birth and contingency plans in the event of complications like transport, place of referral, etc. ${ }^{(29)}$

The minimum number of antenatal care visits during pregnancy recommended by UNICEF and WHO is four. These visits help to provide key services to pregnant women, including measures to detect and treat malaria and anaemia; tetanus immunization; management of sexually transmitted infections and antiretroviral therapy for HIV-positive pregnant women; and the provision of vital information to pregnant women on the risks in pregnancy and delivery (29).

In the qualitative part of the present study, some reasons were found about why mothers did not obtain ANC. Those reasons were habitual, economic factor, surrender to fate for something to happen, the distance of health facility and home. Meanwhile, the mother's reasons for obtaining ANC were closely depending on the level of family income, habitual, knowledge and concern about the pregnancy. Interviews with the midwife found that the reasons that the mothers did not obtain ANC or obtained the ANC $<4$ times were the distance between the health facility and the home and incomplete pregnancy examination. 
Table 4: Characteristic of maternal and child health services

\begin{tabular}{|c|c|c|c|c|}
\hline \multirow[t]{2}{*}{ Characteristics } & \multicolumn{2}{|c|}{ Case } & \multicolumn{2}{|c|}{ Control } \\
\hline & $\mathrm{n}$ & $\%$ & $\mathbf{n}$ & $\%$ \\
\hline \multicolumn{5}{|l|}{ ANC } \\
\hline - Appropriate care & 140 & 56.0 & 205 & 82.0 \\
\hline - Inappropriate care & 110 & 44.0 & 45 & 18.0 \\
\hline Total & 250 & 100.0 & 250 & 100.0 \\
\hline Mean \pm sd & $3.7 \pm 2.0$ & & $5.0 \pm 2.8$ & \\
\hline \multicolumn{5}{|l|}{ Place of Delivery } \\
\hline - Home & 104 & 41.6 & 79 & 31.6 \\
\hline - Posyandu & 1 & 0.4 & 1 & 0.4 \\
\hline - Poskesdes & 8 & 3.2 & 14 & 5.6 \\
\hline - Pustu & 6 & 2.4 & 8 & 3.2 \\
\hline - BPS & 49 & 19.6 & 68 & 27.2 \\
\hline - Puskesmas & 2 & 0.8 & 14 & 5.6 \\
\hline - Private clinic & 3 & 1.2 & 3 & 1.2 \\
\hline - Hospital & 77 & 30.8 & 63 & 25.2 \\
\hline Total & 250 & 100.0 & 250 & 100.0 \\
\hline \multicolumn{5}{|l|}{ Level of health facility } \\
\hline - Level 1 & 63 & 43.4 & 103 & 60.6 \\
\hline - $\quad$ Level 2 & 82 & 56.6 & 67 & 39.4 \\
\hline Total & 145 & 100.0 & 170 & 100.0 \\
\hline \multicolumn{5}{|l|}{ Birth Attendant } \\
\hline - TBA & 22 & 8.8 & 8 & 3.2 \\
\hline - Nurse & 1 & 0.4 & 0 & 0 \\
\hline - Midwife & 175 & 70.0 & 194 & 77.6 \\
\hline - Medical doctor & 1 & 0.4 & 0 & 0 \\
\hline - O\&G specialist & 51 & 20.4 & 48 & 19.2 \\
\hline Total & 250 & 100.0 & 250 & 100.0 \\
\hline \multicolumn{5}{|l|}{ Mode of Delivery } \\
\hline - Vacuum extraction & 1 & 0.4 & 0 & 0 \\
\hline - Section caesarean & 36 & 14.4 & 41 & 16.4 \\
\hline - Normal & 213 & 85.2 & 209 & 83.6 \\
\hline Total & 250 & 100.0 & 250 & 100.0 \\
\hline \multicolumn{5}{|l|}{ Referral } \\
\hline $\begin{array}{l}\text { - The baby was born at home / } \\
\text { Posyandu/poskesdes/ BPS and did not } \\
\text { refer }\end{array}$ & 94 & 56.0 & 147 & 86.4 \\
\hline $\begin{array}{l}\text { - The baby was born at home / } \\
\text { Posyandu/poskesdes/ BPS and referred }\end{array}$ & 74 & 44.0 & 23 & 13.6 \\
\hline Total & 168 & 100.0 & 170 & 100.0 \\
\hline \multicolumn{5}{|l|}{ Neonatal Visit } \\
\hline - Appropriate care & 239 & 95.6 & 198 & 79.2 \\
\hline - Inappropriate care & 11 & 4.4 & 52 & 20.8 \\
\hline Total & 250 & 100.0 & 250 & 100 \\
\hline
\end{tabular}

The qualitative part also described some reasons why a mother did not obtain a pregnancy examination more than four times. These reasons included: non-satisfaction with the services that had been given and so did not return to the same clinic; economic factors - they did not have money to return to the health facility; midwife only came $<4$ times to the home and did not return on a regular basis expecting them to attend the health facility for examination. Meanwhile, the reasons mothers gave for attending $\geq 4$ times of ANC were: satisfied with services and were happy to return to the same place for examination, economic factor - the mothers did not have enough of money although they still had a check-up with O\&G specialist. The other reason was higher knowledge; the mother had good knowledge about the advantages of ANC. 
TABLE 5: Simple logistic regression analysis: Association between maternal and child health services factors and neonatal mortality among LBW neonates

\begin{tabular}{|c|c|c|c|c|}
\hline \multirow[b]{2}{*}{ Variables } & \multicolumn{2}{|c|}{ Group } & \multirow[b]{2}{*}{$\begin{array}{c}\text { OR } \\
95 \% \mathrm{Cl}\end{array}$} & \multirow[b]{2}{*}{$P$ value } \\
\hline & $\begin{array}{l}\text { Case } \\
\mathrm{f}(\%)\end{array}$ & $\begin{array}{l}\text { Control } \\
\text { f (\%) }\end{array}$ & & \\
\hline $\begin{array}{l}\text { Antenatal care } \\
\text { - Inappropriate care } \\
\text { - Appropriate care }\end{array}$ & $\begin{array}{l}110(44.0) \\
140(56.0)\end{array}$ & $\begin{array}{c}45(18.0) \\
205(82.0)\end{array}$ & $\begin{array}{c}3.57 \\
(2.38-5.38)\end{array}$ & $<0.001^{*}$ \\
\hline $\begin{array}{l}\text { Place of delivery } \\
\text { - Non health facility } \\
\text { - Health facility }\end{array}$ & $\begin{array}{l}105(42.0) \\
145(58.0)\end{array}$ & $\begin{array}{c}80(32.0) \\
170(68.0)\end{array}$ & $\begin{array}{c}1.53 \\
(1.0-2.21)\end{array}$ & $0.021^{*}$ \\
\hline $\begin{array}{l}\text { Level of health facility } \\
\text {-Level } 1 \\
\text { - Level } 2\end{array}$ & $\begin{array}{c}67(65.0) \\
103(35.0)\end{array}$ & $\begin{array}{l}82(56.5) \\
63(43.5)\end{array}$ & $\begin{array}{c}1.0 \\
(1.00-1.01)\end{array}$ & $0.022^{*}$ \\
\hline $\begin{array}{l}\text { Birth attendant } \\
-\quad \text { TBA } \\
-\quad \text { Health workers }\end{array}$ & $\begin{aligned} 22 & (8.8) \\
228 & (91.2)\end{aligned}$ & $\begin{array}{c}8(3.2) \\
242(96.8)\end{array}$ & $\begin{array}{c}2.91 \\
(1.27-6.68)\end{array}$ & 0.11 \\
\hline $\begin{array}{l}\text { Mode of delivery } \\
\text { - High risk } \\
\text { - Low risk }\end{array}$ & $\begin{array}{c}37(14.8) \\
213(85.2)\end{array}$ & $\begin{array}{c}42(16.8) \\
208(83.2)\end{array}$ & $\begin{array}{c}0.86 \\
(0.53-1.39)\end{array}$ & 0.540 \\
\hline $\begin{array}{l}\text { Referral } \\
\text { - } \quad \text { High risk } \\
\text { - } \quad \text { Low risk }\end{array}$ & $\begin{array}{c}25(14.3) \\
149(85.7)\end{array}$ & $\begin{array}{l}74(43.7) \\
95(56.3)\end{array}$ & $\begin{array}{c}1.0 \\
(0.99-1.0)\end{array}$ & 0.666 \\
\hline $\begin{array}{l}\text { Neonatal visit } \\
-\quad \text { Inappropriate care } \\
-\quad \text { Appropriate care }\end{array}$ & $\begin{aligned} 11 & (4.4) \\
239 & (95.6)\end{aligned}$ & $\begin{array}{c}52(20.8) \\
198(79.2)\end{array}$ & $\begin{array}{c}0.17 \\
(0.8-0.34)\end{array}$ & $<0.001^{*}$ \\
\hline
\end{tabular}

Significant variable: $p<0.05$

Table 6: Multiple logistic regression analysis: The influence factors of neonatal death among LBW Neonate

\begin{tabular}{lrrrrrrrr}
\hline & & & & & & & \multicolumn{2}{c}{ 95\% C.I.for EXP(B) } \\
\cline { 7 - 9 } Variables & B & S.E. & Wald & df & Sig. & Exp(B) & Lower & Upper \\
\hline ANC & 1.307 & .227 & 33.121 & 1 & $.000^{*}$ & 3.696 & 2.368 & 5.769 \\
Neonatal visit & -1.978 & .363 & 29.678 & 1 & $.000^{*}$ & .138 & .068 & .282 \\
Level of health facility & .015 & .004 & 10.713 & 1 & $.001^{*}$ & 1.015 & 1.006 & 1.023 \\
Place of delivery & .246 & .074 & 11.071 & 1 & $.001^{*}$ & 1.279 & 1.106 & 1.478 \\
Constant & -1.520 & .408 & 13.884 & 1 & $.000^{*}$ & .219 & & \\
\hline
\end{tabular}

Although the ANC is recommended 4 times during pregnancy, and the mother had received ANC $\geq 4$ times, it does not guarantee that the mother and child will be healthy and survive. The contribution of care during pregnancy to the improvement of the outcome is unclear, possibly because the high variability of the quality of care makes comparisons difficult. When the quality of care is poor, even numerous visits will not improve the outcome for the mother or the baby. However, even a few antenatal visits, no matter which standards of protocol of care need to be followed, may have a significant impact on outcomes. In the present study, the researcher did not explore the quality of ANC because of limited documentation in that regard. In retrospective data, the data concerning the frequency of pregnancy examination was easier to obtain from the study site.

The second stronger predictor of neonatal mortality was place of delivery. Neonates who were born at home had 1.2 times greater risk of death than neonates who were born in health facilities. Although in the Indonesia health regulations stated that delivery must be carried out in health facilities (20), but still around $8.8 \%$ of deliveries assisted by health workers are carried out at home. Meanwhile, more than $10 \%$ of births assisted by traditional birth attendants are done at home ${ }^{(28)}$. The purpose of delivery in a health facility is for quick response to the emergency 
case, where the mothers and babies who have complications to receive prompt and appropriate help. This prompt and appropriate help will prevent the occurrence of morbidity and mortality in the mother and baby ${ }^{(5)}$. The results of this study are similar to the previous studies (24), (30), (31), (32).

Level of health facility also as the predictor of neonatal mortality among LBW. Neonates who were born at level 1 health facility (community health centre and private midwifery practice) had 1 times greater risk of death than neonates who were born at level 2 health facility, such hospital type A-D. Differences in health facilities and human resources make a difference in health services between health facilities level 1 and 2 . The maternal and neonatal health services in the Indonesian health system is structured and tiered to include a referral system for obstetric and neonatal emergency cases. The Indonesia ministry of health divide the health facilities for maternal and child health services into 2 levels, these are (33):

- Level 1: Poskesdes, Pustu, BPS, Private clinic and Puskesmas. The health services in level 1 , consists of: ANC, Early detection of the risk factors and complication to the newborn, normal delivery, complication of delivery (only in Puskesmas, and in accordance with the centre's competency), post-natal care, neonatal care and family planning

Level 2 (advanced): Government hospitals (in district or capital province) and private hospitals. The health services in level 2 consist of: ANC, delivery with complications and of high risk factors, complications of the newborn, complications of the high risk postnatal and family planning with long term contraception (Tubectomy and vasectomy).

The delivery at the level 2 health facility will reduce the risk of death and illness in the mother and her baby because these facilities assist in case of an emergency. In the qualitative study, found that in general, mothers will delivery at level 2 health facility if they have complications detected in their pregnancy or because they are referred by health facility level 1 . Some of the respondents said they were not comfortable delivery at health facility level 2 , because they were far from the home and there were too many rules in those places. If they have an option, most of the respondents said they prefer for delivery at health facility level 1.

This study also found that neonatal visits was a protective factor in neonatal mortality among the LBW. Similar results were found in previous studies $^{(34)}$. The neonatal visits in Indonesia was defined in the health services according to a minimum standard of at least three times during the neonatal period. The standard includes injection of vitamin $\mathrm{K}$, giving eye ointment, immunization, physical examination and counselling to mother or family on how to care for the baby (35), (36). In respect to the lack of documentation about the implementation of neonatal visit in the field, this study only explored a small number of visits and the mother's perception about the home visit.

In the qualitative part found that the mother's perceptions concerning neonatal visit were included. Some of the mothers stated they were satisfied with the services that are provided by the health workers to their neonates. Some of them stated they were not satisfied with health providers, because they came to their home only after the baby died and only for the collection of the mortality data. Then other mothers said the neonatal visit services were fair. Meanwhile, interviews with the midwives found that no special care is provided for LBW neonates when the neonatal visit occurred, except counselling.

The results of this study indicate that $\mathrm{MCH}$ services greatly affect the survival of LBW babies in the neonatal period. The appropriate of health services in health facilities are needed to reduce the NMR and improve the health of neonate. The appropriate level of health services should be supported by the skilled of health personnel when providing services. Skilled of health personnel important for patients and are expected when the patient get health care ${ }^{(37)}$. The skill is not only required when they are giving treatment, but also when providing counselling to mother and family. Neonatal homecare could not work well if the mother and family did not get enough information related the care of LBW neonates at home. Counselling about neonatal care is very important to improve the health status and prevent mortality of LBW neonate.

\section{CONCLUSION}

The seven variables tested in this study explain their influence on neonatal death among LBW in Aceh Province, Indonesia. There were: ANC, place of delivery, level of health facility and neonatal visit. The strongest predictor of neonatal death in this study was ANC. The LBW neonates who were born to mothers who received number ANC equal to 3 times had a 3.6 times higher risk of death, than neonates who were born to the mothers who received $\mathrm{ANC} \geq 4$ times.

\section{ACKNOWLEDGMENTS}

We would like to thanks all the participants who had participated in this study and grateful to the head of Aceh province health office, head of district health office, head of Puskesmas and head of maternal and child Health team in Puskesmas who had been helpful to us during the study period. 


\section{REFFRENCES}

1. WHO. Millennium Development Goals (MDGs) [Internet]. 2018. Available from: https: / /www.who.int/news-room/factsheets/detail/millenniumdevelopment-goals-(mdgs)

2. UNICEF. Neonatal Mortality [Internet]. $2018 . \quad$ Available from: https: / /data.unicef.org/topic/childsurvival/neonatal-mortality/

3. UNICEF. Maternal and Newborn Health Disparities in Indonesia. Rep UNICEF 2016 [Internet]. 2016;135-40. Available from: http://dx.doi.org/10.1016/B9781-4160-4390-4.00016-3

4. WHO. World Health Statistic 2015. 2015.

5. WHO. Maternal Mortality [Internet]. 2018 [cited 2019 Feb 20]. Available from: https://www.who.int/news$\mathrm{room} /$ fact-sheets/detail/maternalmortality

6. Say L, Chou D, Gemmill A, Tunçalp Ö, Moller AB, Daniels J, et al. Global causes of maternal death: A WHO systematic analysis. Lancet Glob Heal. 2014;2(6):323-33.

7. Fottrell E, Osrin D, Alcock G, Azad K, Bapat U, Beard J, et al. Cause-specific neonatal mortality: Analysis of 3772 neonatal deaths in Nepal, Bangladesh, Malawi and India. Arch Dis Child Fetal Neonatal Ed. 2015;100(5):F439-47.

8. WHO. Low Birth Weight: Country, Regional, Global Estimates [Internet]. Vol. 9, Man. 2004. 93-102 p. Available from:

http://www.jstor.org/stable/10.2307/ 2800038

9. Lawn J, McCarthy B, Rae Ross S. The Heathy Newborn. 2001; Available from: https://www.k4health.org/sites/defaul t/files/The Healthy Newborn - A reference manaual (Introduction).pdf

10. Bhaskar RK, Deo KK, Neupane U, Chaudhary Bhaskar S, Yadav BK, Pokharel HP, et al. A Case Control Study on Risk Factors Associated with Low Birth Weight Babies in Eastern Nepal and Iran. Int J Pediatr [Internet]. 2015;2015:1-7. Available from: http://www.hindawi.com/journals/ijp edi/2015/807373/
11. AbdalQader MA, Shah SA, Isa ZM, Ghazi HF, Badilla I, Hasan TN. Factors related to low birth weight babies in Baghdad city, Iraq. Malaysian J Public Heal Med. 2014;14(2):45-9.

12. Demelash H, Motbainor A, Nigatu D, Gashaw K, Melese A. Risk factors for low birth weight in Bale zone hospitals, South-East Ethiopia: A case-control study. BMC Pregnancy Childbirth. BMC Pregnancy and Childbirth; 2015;15(1):110.

13. Satrinawati, Sutan R. The impact of maternal factors on neonatal mortality among low birth weight in Aceh Province, Indonesia. Int J Public Heal Res [Internet]. 2014;2014:472-9. Available from: http: / / journalarticle.ukm.my/8132/1/ vol_4_no_2_2014_61.pdf

14. Berkat S. Exclusive Breastfeeding and the Impact on Neonatal Mortality of Low Birth Weight. Int J Curr Res Acad Rev. 2018;6(6):9-15.

15. Miko A, Berkat S. THE SECOND-HAND SMOKE IN PREGNANCY AND ITS IMPACT TOWARD LOW BIRTH WEIGHT IN DISTRICT OF ACEH BESAR , ACEH PROVINCE , INDONESIA. 2017;17(3):11724.

16. Nayeri $F$, Dalili $H$, Nili $F$, Amini $E$, Ardehali A, Khoshkrood Mansoori B SM. Risk factors for neonatal mortality among very low birth weight neonates. Acta Med Iran. 2015;30(51 (5)):6.

17. Lim JW, Chung SH, Kang DR, Kim CR. Risk factors for cause-specific mortality of very-low-birth- weight infants in the Korean Neonatal Network. J Korean Med Sci. 2015;30(June 2014):S35-44.

18. UNICEF. Low Birth Weight [Internet]. 2014 [cited 2019 Jan 3]. Available from: https://data.unicef.org/topic/nutrition /low-birthweight/

19. Dan BKKBN. Survei demografi dan kesehatan 2017. 2017.

20. Kementerian Kesehatan RI. PMK No. 97 Tahun 2014 Tentang Pelayanan Kesehatan Kehamilan. 2014;

21. Sekretariat Negara RI. Peraturan Pemerintah RI No 61 Tahun 2014 [Internet]. 2014. p. 55. Available from: http://ir.obihiro.ac.jp/dspace/handle/ 10322/3933 
22. Dinkes Prov Aceh. Profil Kesehatan Provinsi Aceh Tahun 2015. Banda Aceh; 2016.

23. Kemenkes RI B. Hasil Utama RISKESDAS 2018. 2018;88.

24. Sutan R, Berkat S. Does cultural practice affects neonatal survival- a case control study among low birth weight babies in Aceh Province, Indonesia. BMC Pregnancy Childbirth. 2014;

25. Arunda M, Emmelin A, Asamoah BO. Effectiveness of antenatal care services in reducing neonatal mortality in Kenya: Analysis of national survey data. Glob Health Action [Internet]. Taylor \& Francis; 2017;10(1). Available from: https://doi.org/10.1080/16549716.201 7.1328796

26. Ibrahim J, Yorifuji T, Tsuda T, Kashima $\mathrm{S}$, Doi H. Frequency of antenatal care visits and neonatal mortality in Indonesia. J Trop Pediatr. 2012;58(3):184-8.

27. Satrinawati. Determinant Factors of Neonatal Mortality Among Low Birth Weight in Aceh Province, Indonesia. National University of Malaysia; 2014.

28. Kemenkes RI. Data dan Informasi 2015; Profil Kesehatan Indonesia. Jakarta; 2016.

29. UNICEF. the States of World Female and Children. 2009.

30. Ajaari J. Impact Of Place Of Delivery On Neonatal Mortality In Rural Tanzania. Value Heal. 2013;16(3):A209-10.

31. Tura G, Fantahun M, Worku A. The effect of health facility delivery on neonatal mortality: Systematic review and meta-analysis. BMC Pregnancy Childbirth [Internet]. BMC Pregnancy and Childbirth; 2013;13(1):1. Available from: BMC Pregnancy and Childbirth

32. Moyer CA, Dako-Gyeke P, Adanu RM. Facility-based delivery and maternal and early neonatal mortality in subsaharan Africa: A review of regional literature. Afr J Reprod Health [Internet]. 2015;17(3):30-43. Available from:

https://www.ajol.info/index.php/ajrh/ article/view/93744

33. Kemenkes. Buku Saku Jampersal [Internet]. Jakarta; 2011. 1-12 p. Available from: http://www.depkes.go.id/resources/d ownload/promosi-kesehatan/bukusaku-jampersal.pdf

34. Kananura RM, Tetui M, Mutebi A, Bua JN, Waiswa P, Kiwanuka SN, et al. The neonatal mortality and its determinants in rural communities of Eastern Uganda. Reprod Health [Internet]. Reproductive Health; 2016;13(1):1-9. Available from: http: / /dx.doi.org/10.1186/s12978-0160119-y

35. Kemenkes RI. Buku KIA. Jakarta; 2016. $88 \mathrm{p}$.

36. Manu A, Amenga-Etego S, Weobong B, Danso S, Gyan T, Kirkwood BR, et al. Effect of the Newhints home-visits intervention on neonatal mortality rate and care practices in Ghana: a cluster randomised controlled trial. Lancet [Internet]. Elsevier Ltd; 2013;381(9884):2184-92. Available from:

http: / /dx.doi.org/10.1016/S01406736(13)60095-1

37. Jadoo SAA, Aljunid SM, Sulku SN, Puteh SEW, Ahmed Z, Manaf MRA, et al. Peoples expectations from healthcare providers - A Turkish perspective. Malaysian J Public Heal Med. 2013;13(2):88-97. 